\title{
POLÍTICAS ANTI-PLÁGIO
}

A Revista Universitas: Relações Internacionais preza pela comunicação científica de alto nível e prioriza a publicação de trabalhos oriundos de pesquisa científica. A prática de plágio constitui crime de direito autoral previsto pela Lei No. 9.610, de 19 de fevereiro de 1998. A equipe editorial dispõe de software mediante o qual todos os arquivos submetidos à Revista estão sujeitos a este controle. Em caso de identificação de plágio de até $10 \%$ no artigo enviado à Revista, a equipe editorial enviará ao (à) autor (a) o relatório gerado pelo software, que indica as porcentagens de trechos do texto que remetem a obras anteriormente publicadas e não citadas. Cada autor (a) terá um prazo de até 30 dias para justificar este procedimento e alterá-lo, de acordo com as instruções da equipe editorial. Caso o sistema anti-plágio identifique um percentual acima de 10\% do texto enviado à Revista, o texto será recusado e o autor será devidamente informado acerca do motivo da recusa, seguido do relatório das porcentagens de plágio identificadas. Mesmo neste caso, o(a) autor(a) terá um prazo de 20 dias para recorrer da decisão da equipe editorial. Este processo deverá ocorrer exclusivamente por meio de comunicação eletrônica para o endereço: universitas.rel@uniceub.br.

\section{Equipe Editorial da Revista Universitas: Relações Internacionais}

